\title{
The Dynamics of Bacterial Communities During Traditional Nata de Coco Fermentation
}

\author{
CECILIA ANNA SEUMAHU ${ }^{1 \neq}$, ANTONIUS SUWANTO², \\ DEBORA HADISUSANTO ${ }^{3}$, AND MAGGY THENAWIJAYA SUHARTONO ${ }^{3}$
}

${ }^{1}$ Graduate School of Biotechnology, Institut Pertanian Bogor, Darmaga Campus, Bogor 16680, Indonesia

${ }^{2}$ Department of Biology, Institut Pertanian Bogor, Darmaga Campus, Bogor 16680, Indonesia

${ }^{3}$ PT. Niramas Utama, Jalan Raya Bekasi Tambun Km 39.5, Bekasi 17510 , Indonesia

${ }^{3}$ Department of Food Technology and Nutrition, Institut Pertanian Bogor, Darmaga Campus, Bogor 16680, Indonesia

\begin{abstract}
One of the important problems in traditional Nata de Coco (Nata) fermentation is production inconsistency due to strain or genetic variability reflecting mixed microbial communities involved in this process. This research was aimed at examine the population dynamics of the bacterial community during the fermentation processes. Samples were collected daily for six days from fermentation media derived from "good" and "bad" Nata fermentation. We compared the levels of bacterial diversity through amplified 16S-rRNA (ARDRA). DNA was extracted directly from the fermentation media and 16S-rRNA gene was amplified employing Universal Bacterial Primers. The amplicons were cloned into pGEM-T Easy vector, and restriction enzymes HaeIII and RsaI were used to generate ARDRA profiles. ARDRA phylotypes of DNA extracted from the fermentation medium obtained from different Nata qualities were compared. Phylotype profiles demonstrated unique bacterial community profiles for different conditions of Nata quality, which could be developed as a parameter to monitor Nata quality during fermentation. In this research we found that the dynamics of the bacterial population involved in Nata fermentation were a crucial factor for determining traditional Nata quality.
\end{abstract}

Key words: Nata de Coco, bacterial community dynamics, ARDRA

Traditional Nata fermentation process is not yet fully studied nor comprehended at the molecular level, although the process has enough reason to be explored. Randazzo et al. (2002), have studied community activity and the dynamics of bacterium populations during cheese production. Ampe et al. (2001), also studied the "Sour Cassava" fermentation process and they found that the dynamics of microorganisms was sequentially changed during the fermentation process. We consider that if we studied the dynamics of the microbial population, we could have better understanding on the role of microorganisms in the fermentation processes so that we can systematically establish a consistent Nata starter culture.

Population dynamics need to be studied through community analysis because it represents an excellent approach to comprehending the function and structure of a community. This analysis gives the opportunity to identify dominant and unique strains in a controlled environment (Marsh et al. 2000). Giraffa and Neviani 2001, reported that the first step to comprehend these concepts in food microbiology is to analyze microbiological profiles and community structures and dynamics; and also their functions in altering the environment and biologic conditions in food.

The challenge is the difficulty in cultivating all microorganisms from food on laboratory standard media since most microorganisms from nature are not yet culturable. (Giraffa and Neviani 2001). Ampe et al. (1999), have compared the standard microbiological techniques, and technique that do not depend on cultivated processes, to examine microbial

\footnotetext{
†Present address, Universitas Pattimura, Jalan Ir. M. Putuhena, Kampus Poka, Ambon 97233, Indonesia

${ }^{*}$ Corresponding author, Phone/Fax: +62-251-362830,

E-mail: asuwanto@indo.net.id
}

populations. They found that the culture-independent technique is the most suitable to depict population dynamics.

Weisburg et al. 1991, found that amplification of the 16SrRNA gene, cloning and sequencing it represents one of the important methods to identify microorganisms directly from nature (culture-independent). This technique is essential in studying the dynamics of the microbial population in Nata fermentation due to the extreme $\mathrm{pH}$ of media via the acid cultivation conditions ( $\mathrm{pH} 2-3$ ). Our previous investigations indicated that not all of the bacteria involved in Nata fermentation could be cultured. This research aims to study the diversity and dynamics of the bacterial population during traditional Nata de Coco fermentation.

\section{MATERIALS AND METHODS}

Nata media solution from the fermentation processes with the Bad and Good outcomest were sampled at days 5, 6, 7, 8, 9 , and 11 for ARDRA. Nata media solution was categorized as "Good" if it yielded Nata with a thick and smooth texture. In contrast, a Nata media solution was categorized as "Bad" if it yielded Nata with the hard texture that had bubbles of gas trapped in it.

One of the A. xylinum collection Strain IB-1 was marked by molecular marker to become $A$ xylinum Strain IB-1Nal-R. This was used to analyse growth of $A$. xylinum and the roles of other bacteria in fermentation media. Samples of media and strains of $A$. xylinum used in this study were collected from a Nata de Coco company in Jakarta.

Growth Analysis. Acetobacter xylinum Strain IB-1, which is initially sensitive to nalidixic acid, was screened for spontaneous nalidixic-resistant mutans by cultivating it repeatedly at media suplemented with that antibiotic. A. xylinum 
Strain IB-1Nal-R, which is resistant to nalidixic acid, was subsequently grown in media without antibiotic supplementation as control (Meds), the medium with the addition nalidixic acid $20 \mu \mathrm{g} \mathrm{ml}^{-1}$ (Nal), and the heat-treated medium by boiling at $10 \mathrm{~min}(\mathrm{Blc})$ to eliminate most vegetative bacterial cells. Bacteria populations grown in different treatments were examined on the first, fifth and tenth days of cultivation. Media used for the growth were as described previously (Seumahu 2005).

DNA Isolation. The isolation of DNA from samples was conducted as reported previously by Ampe et al. (1999).

Amplification and Cloning of the 16S-rRNA Gene. Amplification of the 16S-rRNA gene was conducted employing 63f: 5'-CAggCCTAACACATgCAAgTC-3' and 1387r: 5'gCggWgTgTACAAggC-3' for the Bacteria Domain group (Marchesi et al. 1998).16S-rRna amplicons were purified employing Wizard SV Gel and the PCR Clean-Up System. The purified DNA's were ligated into pGEM-T Easy vector (Promega, Madison, WI, USA) and transformed into Escherichia coli DH5á. Transformants were selected on Luria Agar media (LA)+Ampicilin $\left(100 \mu \mathrm{g} \mathrm{m}^{-1}\right)$ supplemented with X-gal $\left(40 \mu \mathrm{g} \mathrm{ml}^{-1}\right)$. 16S-r-RNA gene in recombination plasmid library (collection of 16S-rRNA genes in pGEM-T vector) were amplified again using M13F and M13R primer (Moffett et al. 2000 ) to obtain individual 16 S-rRNA genes. This step would ensure that the amplified 16S-rRNA genes were from recombination plasmids and not from the bacterial host 16S-rRNA gene.

Amplified Ribosomal DNA Restriction Analysis (ARDRA). The 16S-rRNA gene, amplified from recombination plasmids, was digested with restriction enzymes $R s a \mathrm{I}$ or HaeIII, to yield a specific pattern representative of the existing bacteria and designated as Profile 1, Profile 2, etc. The percentage of specific patterns calculated on each day of fermentation and was depicted as a population dynamic curve.

\section{RESULT}

Growth of $A$. xylinum in the Presence of Microbial Community. Refering to the obtained data, we made a cell growth histogram depicting the growth profiles of $A$. xylinum Strain IB-1Nal-R in fermentation media with different treatments (Fig 1). Fig 1 indicates that fermentation media with a blanching treatment (Blc) did not enhance the growth of Strain IB-1Nal-R compared to that of the control medium (Nata fermentation medium without any treatment). In the fermentation medium with nalidixic supplementation, the growth of IB-1Nal-R became very depressed. Although the population did increase, the sum of the cell count was not as high as that in the control medium or blanching treatment. This result suggested that the pre-existing bacterial population in the media were essential for successful Nata fermentation and migt have positive or synergistic effect to the growth of Strain IB-1-Nal-R.

ARDRA Reveals Bacterial Profiles During Nata Fermentation. Results of ARDRA analysis showed the existence of at least twenty two different bacterial group during Nata fermentation (Fig 2). Each ARDRA profile found in Nata fermentation was calculated as a percentage to the total profiles every day starting from the fifth day up until eleventh day. Five profiles were considered to be unique because their presence could only be found over certain specific days of fermentation (Fig 3). Unique ARDRA profiles include profile 1 to 5 . Profile 6 to 22 was not depicted in a growth curve because we found them only on certain days and they did

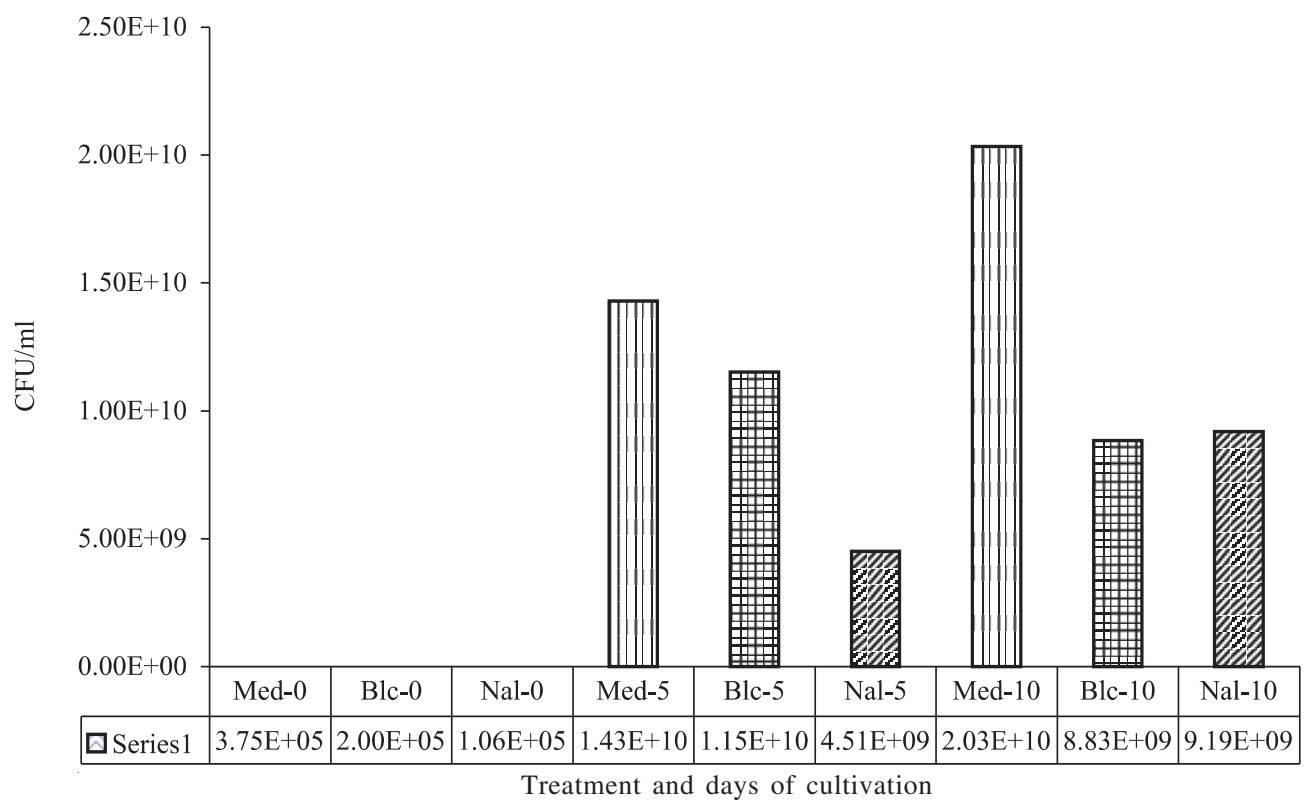

Fig 1 Acetobacter xylinum IB-1Nal-R growth in fermentation Media with different treatments $($ Med = media without treatment, Blc=heated media, $\mathrm{Nal}=$ media with nalidixic acid supplementation $20 \mu \mathrm{g} / \mathrm{ml}$, the number following the name of the media indicates the day of fermentation). The numbers following each treatment indicated the days of Nata fermentation ( 0.5 and 10 days). 
not show significant percentage numbers of the total population (data is not presented at this article).

\section{DISCUSSION}

A. xylinum with antibiotic resistance marker was employed, in the laboratory scale, to examine the influence of some media treatment on the growth of A. xylinum during Nata fermentation. Three kinds of media were used, i.e. media without treatment, media with blanching for 10 minutes to eliminate as many as possible contaminants in the media, and media with nalidixic acid supplementation $\left(20 \mu \mathrm{g} \mathrm{ml}^{-1}\right)$ to suppress the growth of other bacteria sensitive to this antibiotic. The growth of contaminants was expected to be suppressed to give enable to A. xylinum to 'outcompete' and yield pellicle of good Nata gel. Strain IB-1 was marked for the purpose of cell estimation when they were re-grown on media with nalidixic acid supplementation. We assumed that if Strain IB-1Nal-R could be maintained as dominant population, this isolate will grow fast and produce excellent Nata gel.

The results showed that Nata which was produce during the fermentation process, when the natural contaminat population was suppresed with either a blanching treatment or by nalidixic acid supplementation, was inferior in quality compared to that of the control media. Therefore, the presence of foreign bacteria at the control media might have a synergistic effect and stimulate rapid growth of the A. xylinum population. In traditional Nata fermentation, media preparation was often conducted under sterile conditions. How- ever, the fermentation did not always fail or result in 'Bad Nata'. This might explain why the preexisting bacteria in the media preparation and also during the fermentation process, could enhance Nata production and might possibly show exhibit symbiosis or excrete essential factors required for cellulose biosynthesis.

In this study we define 'Good Nata' fermentation as one which will generate a thick (1.5-2 cm), homogenous cellulose gel with high transparency; while 'Bad Nata' fermentation will generate frothy, thin (frequently less than $0.5 \mathrm{~cm}$ ), soft with white or opaque color Nata gel after 8 days of fermentation (Seumahu 2005).

In this study, ARDRA was employed to better understand the bacterial community involved in the production of 'Bad' and 'Good Nata'. This analysis is based on direct extraction of total DNA from both cultured and uncultured bacteria. Specific bacterial strains in the Bacteria Domain could be identified by their specific profiles generated from the electrophoregrams of $16 \mathrm{~S}$ gene digested with restriction enzymes HaeIII or RsaI.

Results of the ARDRA indicated that in a traditional Nata fermentation process, A. xylinum represented seeding during a process which could also have symbiosis, or association with other bacteria present, in either coconut water or coconut milk that might generate a mutual effect in 'Good Nata' production or an antagonistic effect in 'Bad Nata' production.

Bacterial growth pattern shown in Fig 3, indicated a sharp fluctuation for profile $2,3,4$, or 5 during the course of fermentation. In fermentation generating the 'Bad Nata', this
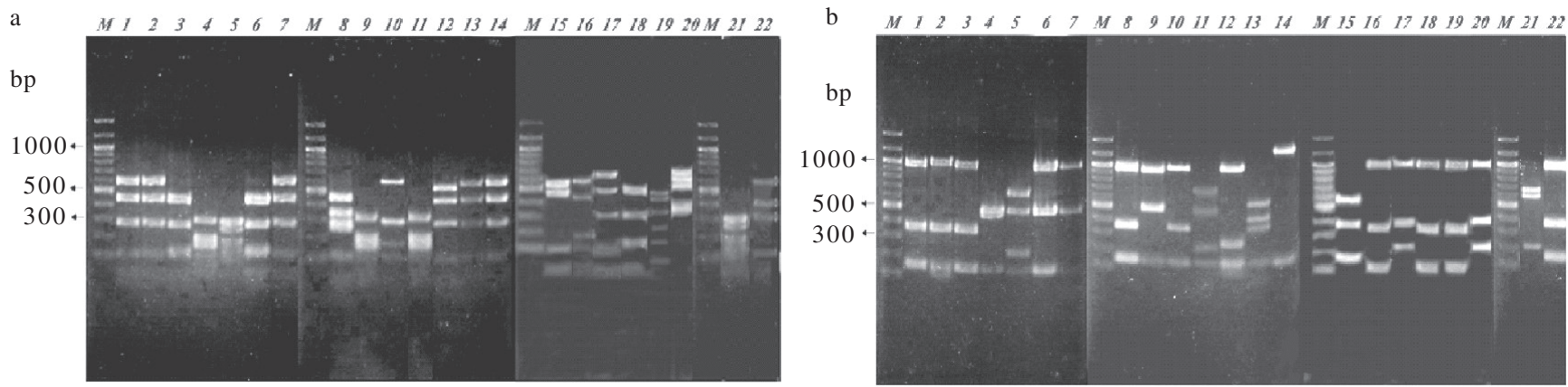

Fig 2 ARDRA profile of HaeIII and RsaI from Bacteria group which emerged during Nata fermentation (a=HaeIII; b=RsaI) (the numbers above every column show individual recombinant 16S-rRNA genes analysed, various type of bacterial profiles $\mathrm{M}=$ molecular marker size).
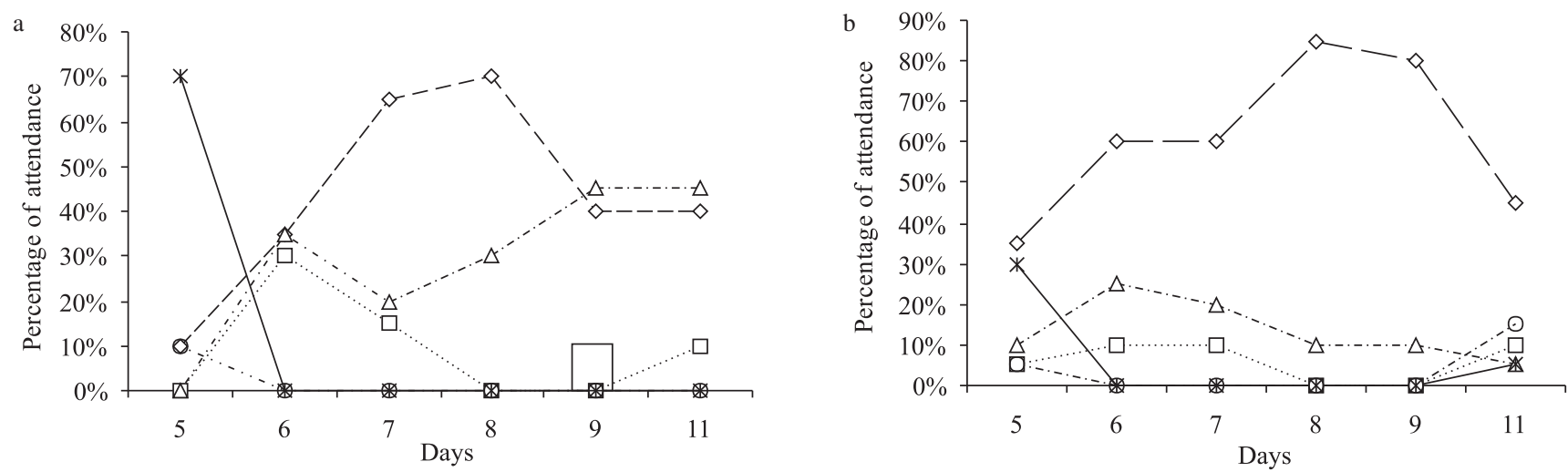

Fig 3 Growth Pattern curve of 5 dominant ARDRA profiles. a. Profiles from Bad, and b. Good Nata fermentations (.- - -) profil 1, (- $\square-)$ profile $2,(-\Delta-)$ profile $3,\left(-\mathrm{O}^{-}\right)$profile $4,(-)$ profile 5 . 
growth profile was very erratic, while at fermentation with a good outcome, this type of profile was less erratic and tended to stabilize over time. Profile 1 did not show any difference of their population dynamics either in the 'Bad' or 'Good Nata' production. Profile 2 in 'Bad' fermentation tends to show fluctuation while in good fermentation it tends to stabilize with a low percentage of variability. On the other hand, profile 4 in both 'Good' and 'Bad' fermentation did not show the existence of different population dynamics.

This fermentation process showed the existence of unique profiles, i.e. profile 3 and 5 from the Bacteria Domain. Profile 3 showed rather sharp difference between 'Bad' and 'Good' Nata in a fermentation resulting in 'Bad Nata', this profile tend to fluctuate and rise in the final fermentation process. On the other hand, in fermentation with the 'Good Nata' the existence of this profile tended to be minimal or was not visible. Profile 5 on fifth day of the fermentation process for the 'bad' result showed the highest percentage (70\%), while on the same day this profile showed only $25 \%$ in a fermentation process until yielded the 'Good Nata'. In a fermentation process with the 'bad' result, this pattern was not detected on subsequent day, while for the fermentation process with a 'good' result, this pattern was still detectable in spite of its low amount (5\%) on eleventh day. We conclude that community unique profiles represent one of the key factor which in this study can be considered essential indicators for 'Bad' or 'Good' Nata fermentation. This analysis could be more dramatic if the sampling had not been limited to begin from day 5 where cellulose pellicles start to emerge.

Another unique matter is the amount of 'other' profiles present in relative small numbers and the flat spreading during the fermentation process with the 'good' result as compared to fermentation process yielding the 'bad' result (data not presented). A possible explanation for the existence of different types of bacteria at different steps represent a symbiosis process, where a different set of bacteria are required at different steps of fermentation to provide essential nutrients to A. xylinum for its cellulose biosynthesis. The presence of these bacteria could supply otherwise deficient, but essential, nutrients which are important for the growth of $A$. xylinum for 'Good Nata' production. This result also indicates that traditional Nata fermentation, which tends to be semi-aseptic, might be required to provide some beneficial bacterial inocula for 'Good Nata' production (Fig 1.) since $A$. xylinum grew better in medium without antibiotic supplementation or having blanching treatment.
Other factors which might have an effect to bacterium population dynamics is the change of $\mathrm{pH}$ of the fermentation medium during the process. At the start of fermentation, the $\mathrm{pH}$ of the media is 3.9. This value droped over time until it reached approximately $\mathrm{pH} 2.0$ at the end of the fermentation. This might have effect on the complexity of the bacterial community profiles.

\section{ACKNOWLEDGGEMENTS}

This research was supported by Research Center for Microbial Diversity, Faculty of Mathematics and Natural Sciences, Bogor Agricultural University, Bogor, and PT Niramas Utama in Jakarta. This Research is part of CAS Thesis.

\section{REFERENCES}

Ampe F, Ben-Omar N, Moizan C, Wacher C, Guyot J. 1999. Polyphasic Study of The Spatial Distribution of Microorganisms in Mexican pozol, a Fermented Maize Dough, Demonstrates the Need for Cultivation-independent methods to investigate traditional fermentations. App Environ Microbiol 65:5467-5473.

Ampe F, Sirvent A, Zakhia N. 2001. Dynamics of Microbial Community Responsible for Traditional Sour Cassava Starch Fermentation Studied by Denaturing Gradient Gel Electrophoresis and Quantitative rRNA Hybridisation. Intl J Food Microbiol 65:4554.

Giraffa G, Neviani E. 2001. DNA-based, Culture Independent Strategies for Evaluating Microbial Communities in Food-associated Ecosystems. Intl J Food Microbiol 67:19-34.

Marchesi JR, Sato T, Weightman AJ, Martin TA, Fry JC, Hiom SJ, Wade WG. 1998. Design and Evaluation of Useful BacteriumSpecific PCR Primer That Amplify Genes Coding for Bacterial 16S rRNA. Appl Environ Microbiol 64:795-799.

Marsh TL, Saxman P, Cole J, Tiedje J. 2000. Terminal Restriction Fragment Length Polymorphism Analysis Program, a Web-based Research Tool for Microbial Community Analysis. Appl Environ Microbiol 66:3616-3620.

Moffet BF, Walsh KA, Harris JA, Hill TCJ. 2000. Analysis of Bacterial Community Structure Using $16 \mathrm{~S}$ rDNA Analysis. Anaerobe 6:129-131.

Randazzo CL, Toriani S, Akkermans DADL, de Vos WM, Vaughan EE. 2002. Diversity, Dynamics and Activity of Bacterial Communities During Production of an Artisanal Sicilian Cheese as Evaluated by $16 \mathrm{~S}$ rRNA Analysis. Appl Environ Microbiol 68:1882-1892.

Seumahu CA. 2005. Analisa Dinamika Populasi Bakteri selama Proses Fermentasi Nata de Coco menggunakan Ampilfied Ribosomal DNA Restriction Analysis (ARDRA) [Thesis]. Bogor: Bogor Agruculture University.

Weisburg WG, Barns SM, Pelletier DA, Jane DJ. 1991. 16S Ribosomal DNA Amplification for Phylogenetic Study. J Bacteriol 173:697-703. 